\title{
Examination of the Capabilities of Some Models of Hand GPS Receivers for Purposes of Creation of Thematic Maps
}

\section{Introduction}

The origin of the creation of satellite navigation systems (GNSS) was the creation of the Global Positioning System by the United States Department of Defense. The works on the creation of NAVSTAR GPS Navigation System with Time and Ranging, popularly known as GPS, lasted more than 20 years. An announcement of the system to be fully operational took place in 1995. The system initially was used only for military purposes, at a later time was also made available for the purposes of civilian users (primarily for navigation by land, air and sea). In the technical assumptions GPS consisted of satellites 24, orbiting the earth on 6 nearly circular orbits, at an altitude of $20200 \mathrm{~km}$ above the Earth. The angle of inclination of satellites orbits relative to the Earth's equator is 55 degrees, and the circulation time of the satellite around the Earth is equal to half the sideral day that is about $11 \mathrm{~h} 57 \mathrm{~min} 27 \mathrm{sec}$.

Currently, in the world there are two fully operative satellite navigation systems (GNSS) described above NAVSTAR GPS and Russian GLONASS. It should also be mentioned that in the near future a European civil system Gallileo, mainly financed from EU funds will be created. A comparison of these GNSS systems contains Table 1.

With the development of GNSS the development of the equipment used in the segment of users took place. In Poland, the first receiver appeared in 1989, it was intended for geodetic works [5].

The subject of this paper refers to a group of GPS receivers, which are mainly used for navigational purposes or simplified GIS studies. However, they have a number of useful features, which can be used in geodesy for tasks involving

* University of Agriculture in Krakow, Faculty of Environmental Engineering and Land Surveying, Krakow, Poland 
data acquisition for updating and even the creation of thematic layers of modern maps. There are three types of hand-held GPS receivers: GPSmap 76, GPSmap 62st (Garmin company) and GPS Nautiz x7 (Handheld company). Garmin company receivers have previously been investigated in terms of their suitability for the selected geodetic works or were tested to find their actual accuracy and precision $[4,6,8,9]$. This publication presents the results of testing them for usefulness in the process of creation of thematic maps. In addition, they were compared with a manual GPS receiver Nautiz 7, which has much greater capabilities and is used for GIS tasks [1-3].

Table 1. Comparison of GNSS systems

\begin{tabular}{|c|c|c|c|}
\hline \multirow{2}{*}{ Parameter } & \multicolumn{3}{|c|}{ GNSS system } \\
\hline & GPS-NAVSTAR & GLONASS & GALILEO \\
\hline $\begin{array}{l}\text { The country } \\
\text { developing system }\end{array}$ & United States & Russia & $\begin{array}{l}\text { The European Union, } \\
\text { Norway, South Korea }\end{array}$ \\
\hline $\begin{array}{l}\text { The planned number } \\
\text { of satellites }\end{array}$ & 24 & 27 & 30 \\
\hline Number of orbits & 6 & 3 & 3 \\
\hline $\begin{array}{l}\text { Inclination of the } \\
\text { orbital to the equator } \\
\text { the Earth }\left[{ }^{\circ}\right]\end{array}$ & 55 & 64.8 & 56 \\
\hline $\begin{array}{l}\text { The height of the orbit } \\
{[\mathrm{km}]}\end{array}$ & 20183 & 19100 & 23626 \\
\hline $\begin{array}{l}\text { Orbital period of the } \\
\text { Earth }\end{array}$ & 11 h 58 min & $11 \mathrm{~h} 16 \mathrm{~min}$ & $14 \mathrm{~h} 21 \mathrm{~min}$ \\
\hline $\begin{array}{l}\text { Date of the fully } \\
\text { operability }\end{array}$ & 17.07.1995 & 2011 & 2016-2018 \\
\hline $\begin{array}{l}\text { Occupied frequencies } \\
\text { [MHz] }\end{array}$ & $\begin{array}{l}\mathrm{L} 1=1575.42 \\
\mathrm{~L} 2=1227.60 \\
\mathrm{~L} 5=1176.45\end{array}$ & $\begin{array}{l}\mathrm{L} 1=1598.06-1604.40 \\
\mathrm{~L} 2=1242.94-1248.63 \\
\mathrm{~L} 3=1201.4\end{array}$ & $\begin{array}{l}\text { E2 }-\mathrm{L} 1-\mathrm{E} 1=1559-1591 \\
\mathrm{E} 6=1260-1300 \\
\mathrm{E} 5 \mathrm{a}+\mathrm{E} 5 \mathrm{~b}=1176.45-1207.14\end{array}$ \\
\hline
\end{tabular}

\section{Specification of Some Models of GPS Receivers}

Figure 1 shows the selected types of handheld GPS receivers, whose functions can be used to some geodetic works, although their primary function is navigation.

Both the Garmin GPSmap 76 and Garmin GPSmap 62st were used by the verification of crop area declared by farmers in the Uniform Area Payments Scheme, carried out by ARMA in the first years after the accession of Poland to the European Union. At present, they are used mainly for navigation or simple geodetic tasks that do not require high precision. These receivers are powered by AA alkaline batteries internally or externally by the antennas 10-40 V DC. An older type of Garmin GPSmap 76 has an internal memory of $8 \mathrm{MB}$ for data from MapSource software series. The device has a built-in road map of Europe. It has standard screens: the status of the satellites, map, 
compass, highway, active route, the list of waypoints, the list of routes, aan a list of traces. Navigation features of the device that are possible to use in surveying are as follows: recording up to 500 waypoints with the name and symbol, 50 routes and 10 traces to 2048 points. Saving the coordinates of new points (waypoints) in the memory of the device is very easy and is done by pressing a single button. Another advantage of this type of receiver is the ability of configuration for the geodetic coordinate systems 1965 and 2000 which in some cases of surveying works much simplifies and speeds up the field works. These issues will be the subject of another broader study.
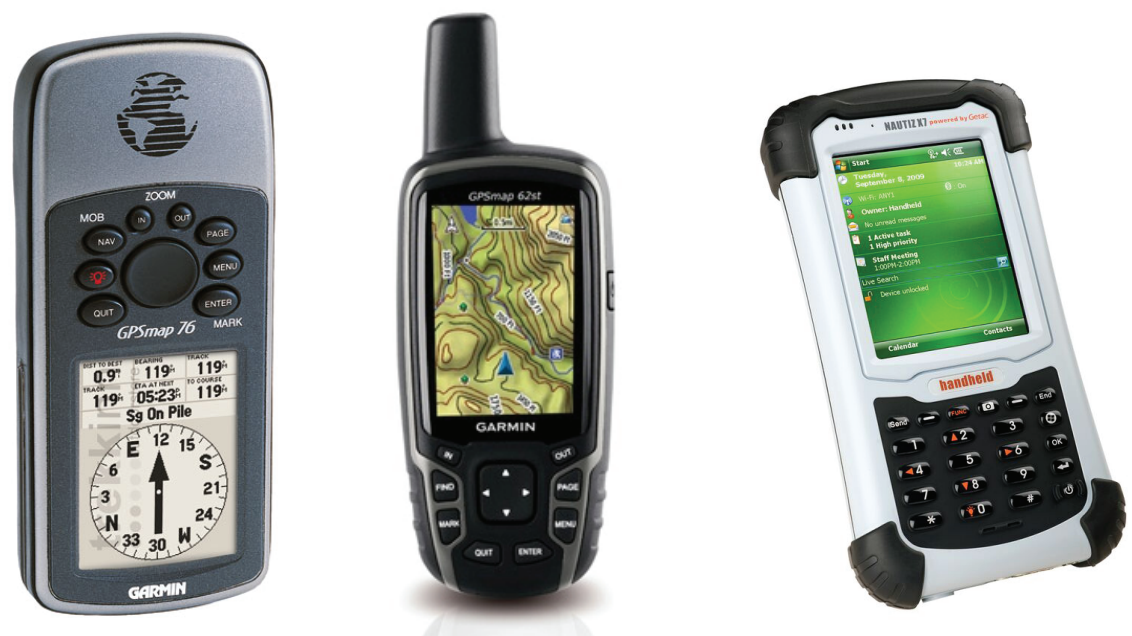

Fig. 1. Garmin GPSmap 76, Garmin GPSmap 62st, Nautiz x7

Source: http://www.trekkinn.com/outdoor-gory/garmin-gpsmap-76/6633/p; http://www.smallgis.pl

Under the screen of both receivers there are eight buttons, each of which has been assigned function and the four-position button, which allows for the selecion of menu options or to move the cursor around the map.

These buttons are the same in the devices GPSmap 76 and GPSmap 62st:

- "In" and "Out" - zooming in or out of the map,

- "Page" - allows to scroll the main pages,

- "Menu" - single pressing displays a menu of options for the currently displayed page, and double pressing allows to skip to the main menu from any page,

- "Enter" - approves the choice,

- "Quit" - allows exit from the selected screen or cancels activities,

- "Mark" - marking of waypoints,

- "Find" - allows to search.

The device has a mini-USB port and MCX connector for GPS antenna and a microSD card slot (under the battery). 
Table 2. Comparison of the physical characteristics of GPSmap 62st, GPSmap 76 and Nautiz x7

\begin{tabular}{|c|c|c|c|}
\hline Compared feature & GPSmap 62st & GPSmap 76 & Nautiz x7 \\
\hline $\begin{array}{l}\text { Dimensions [cm] } \\
\text { display diagonal }\end{array}$ & $\begin{array}{l}6,1 \times 16,0 \times 3,6 \\
6,6 \text { inch }\end{array}$ & $\begin{array}{l}6,9 \times 15,7 \times 3,0 \\
6,6 \text { inch }\end{array}$ & $\begin{array}{l}9,7 \times 17,9 \times 3,7 \\
3,5 \text { inch }\end{array}$ \\
\hline Screen & $\begin{array}{l}\text { TFT } 2,6 \text { inch, } \\
160 \times 240 \text { pixels, } \\
65,000 \text { colors }\end{array}$ & $\begin{array}{l}\text { resolution } \\
180 \times 240 \text { pixels, } \\
\text { information in four } \\
\text { shades of gray }\end{array}$ & $\begin{array}{l}\text { TFT, } 262,000 \text { colors }(18 \text { bit) } \\
\text { resolution VGA } 480 \times 640 \text { pixels., } \\
\text { anti-glare coating, readability in } \\
\text { direct sunlight, technology TMR with } \\
\text { LED backlit }\end{array}$ \\
\hline Weight [g] & 260 & 228 & 490 \\
\hline Keyboard & - & - & numeric backlit screen QWERTY \\
\hline Battery & 2 batteries AA & 2 batteries AA & rechargeable battery $5600 \mathrm{mAh}$ Li-ion \\
\hline $\begin{array}{l}\text { Connection } \\
\text { Memory card slot }\end{array}$ & $\begin{array}{l}\text { port mini-USB and } \\
\text { MCX connector for } \\
\text { GPS antenna and } \\
\text { microSD card slot }\end{array}$ & $\begin{array}{l}\text { RS } 232 \text { data } \\
\text { interface / } \\
\text { power supply of } \\
\text { connector } 4 \text { pin } \\
\text { round Garmin }\end{array}$ & $\begin{array}{l}1 \times \text { USB (host and client) } \\
\text { power supplies } \\
1 \times \text { slot SDIO } \\
\text { 9-pin serial RS-232 }\end{array}$ \\
\hline Waterproof & yes & yes & yes \\
\hline $\begin{array}{l}\text { Temperatures range } \\
{\left[{ }^{\circ} \mathrm{C}\right]}\end{array}$ & -15 to 70 & -15 to 70 & -30 to 60 \\
\hline $\begin{array}{l}\text { Accuracy with } \\
\text { WAAS/EGNOS [m] }\end{array}$ & $3-5$ & $7-10$ & 2 \\
\hline $\begin{array}{l}\text { Communicators } \\
\text { Accessories }\end{array}$ & $\begin{array}{l}\text { GPS with HotFix } \\
\text { and WAAS/ } \\
\text { EGNOS } \\
\text { the function } \\
\text { of wireless } \\
\text { data sending } \\
\text { (waypoints, routes, } \\
\text { tracks, points } \\
\text { geocache) }\end{array}$ & none & $\begin{array}{l}\text { bluetooth } 2.0+\text { EDR } \\
\text { WLAN: built-in } 802.11 \mathrm{~b} / \mathrm{g} \\
\text { GSM/UMTS Modem (HSDPA/EDGE) } \\
\text { Receiver GPS SiRF Star III with } \\
\text { support WAAS/EGNOS } \\
\text { E-Compass and G-Sensor } \\
\text { altimetr digital camera } 3 \mathrm{Mpx} \\
\text { with autofocus and LED flash }\end{array}$ \\
\hline $\begin{array}{l}\text { Software for data } \\
\text { processing }\end{array}$ & $\begin{array}{l}\text { BasicCamp, } \\
\text { MapSource }\end{array}$ & $\begin{array}{l}\text { BasicCamp, } \\
\text { MapSource }\end{array}$ & $\begin{array}{l}\text { ArcPad (internal) } \\
\text { QGIS ArcInfo }\end{array}$ \\
\hline
\end{tabular}

In comparison with GPSmap 76 and the newer type of Garnin GPSmap 62st receiver Nautiz $x 7$ is portable computer of Handheld company. It is equipped with the operating system Windows Mobile 6.1 Professional, processor Xscale $806 \mathrm{MHz}$, $128 \mathrm{MB}$ of RAM and $4 \mathrm{~GB}$ of ROM internal memory. The receiver is powered by 5600 mAh battery, which enables 12 hour operation in the area on a single charge. Some features of this receiver are presented in Table 2 in the comparison with other receivers which are the subject of the study. The big advantage of this device is work in the ArcPad 7.1. It is GIS software. The coordinates of a point are available immediately after touching the map area with the pen. GPS data can be written in two forms: 
log file (dot layer "shape") or in the form of geographical objects of dot, line or surface types. The objects are stored in layers of "the Shape" type. Thanks to this without any problem, you can open the obtained data, eg in the QuantumGIS. The attribute data describing the objects are collected and updated by the ArcPad Forms. These forms include options for text boxes, lists, wizard of the date choice and others, and each can be customized for the requirements of the elaboration (e.g. thematic map). It should be noted, however, that the accuracy of the devive, comparable with the accuracies of hand receivers Garnin GPSmap 76 and Garmin GPS map 62st, does not allow the use of it to create more precise measurements. However, it works perfectly in the creation of thematic maps of informative character, especially for point objects.

All of these types of receivers have common disadvantage, they do not always work well in the areas with a high density of terrain details, where access to the horizon is obscured by the high obstacles: trees, buildings, etc.

\section{Applications of Selected Functions of Hand Receivers}

After conducting several tests of mentioned above types of receivers in the areas with diverse lay of the land - with the help of some of the features of these devices, you can obtain data for simplified thematic elaborations. Among these are:

- development of a profile of the route (eg, walking tours or cycling trail) directly on the device (Fig. 2);

- placing the points directly on the map (eg dangerous points on the road or interesting places on the route) (Fig. 3);

- designing the route on the map based on the recorded tracks and waypoints on the map (such as the shortest route between selected points) (Fig. 4);

- demonstrative or tourism maps (such as transportation routes) (Fig. 5);

- heights $(\mathrm{m})$, distances $(\mathrm{km})$.

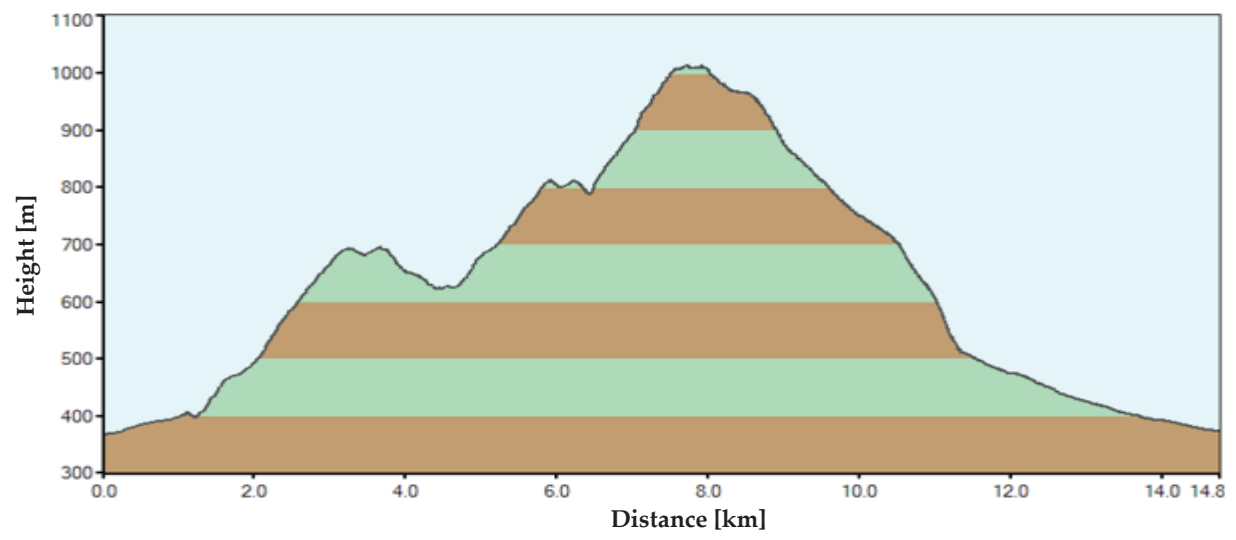

Fig. 2. Graph of heights created on the basis of the hand receiver GPSMap 76 measurements for the selected section of the trail in the Silesian Beskid 


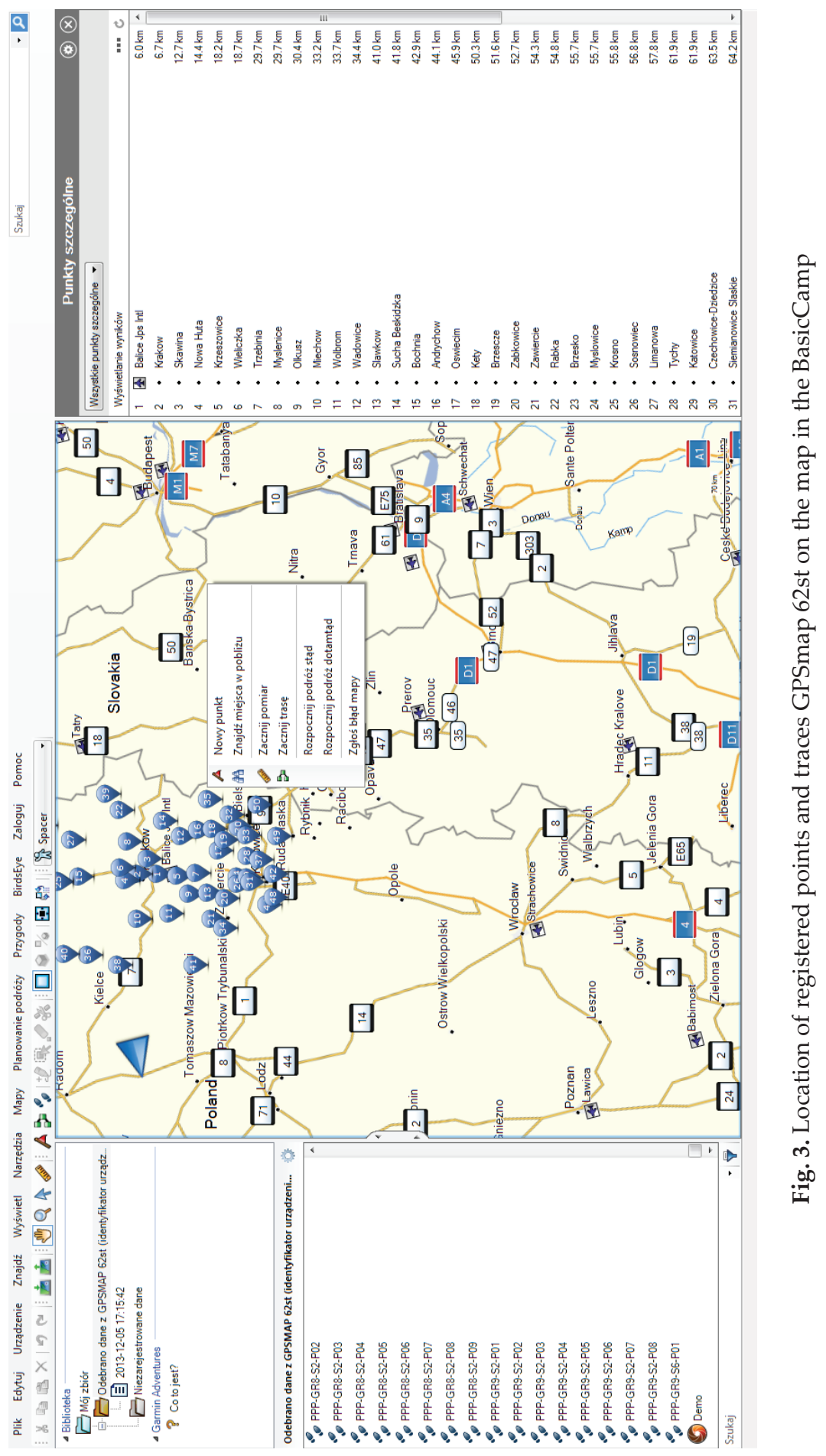




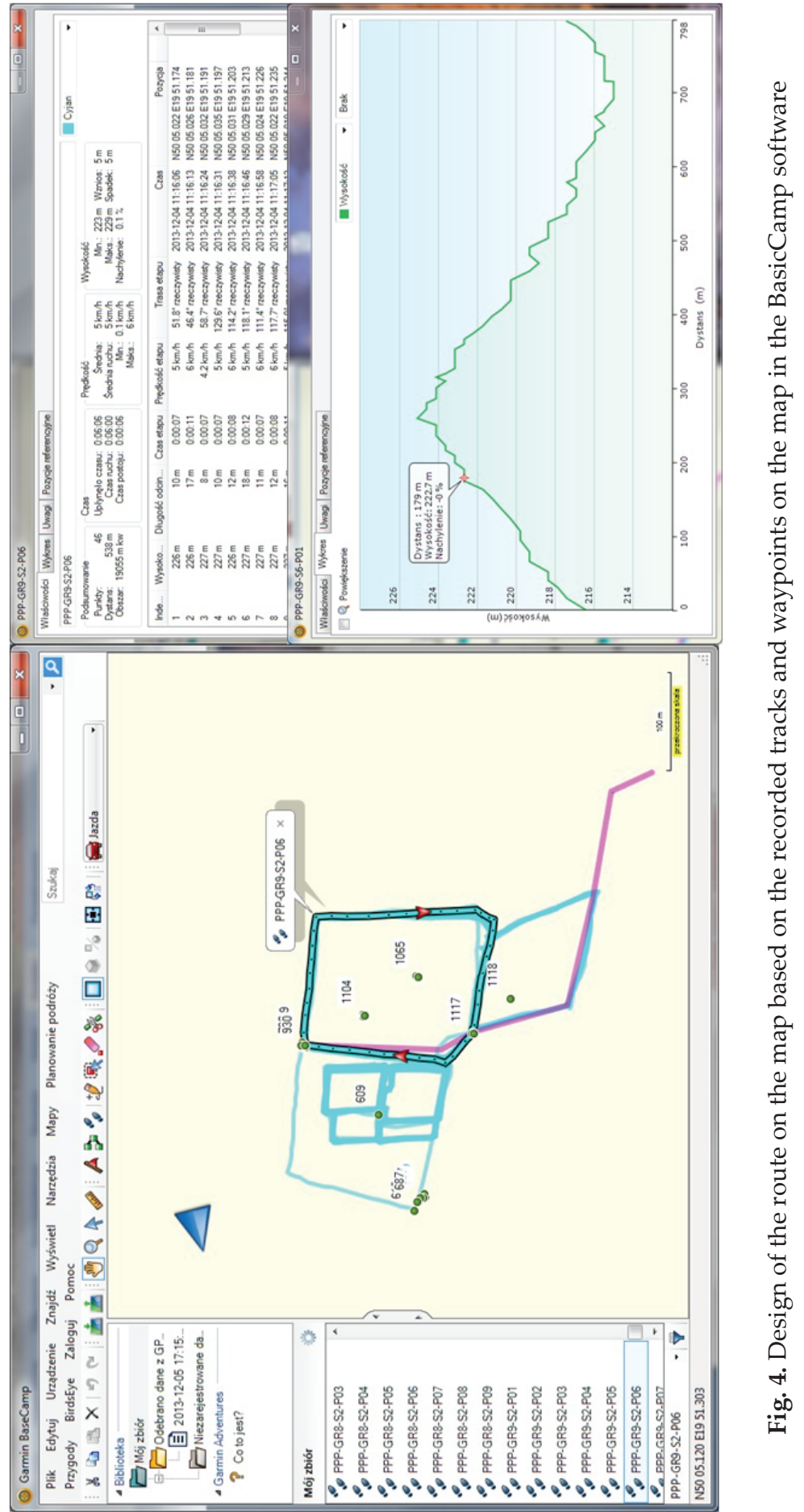


The measurement data from each receiver of the type described above can be listed in the QGIS software. The preparatory work should start by preparing the content of the underlay eg using geoservices Geoportal.gov.pl or OpeenStreetMap.

A coordinate measurement using receivers GPSmap 62st and GPSmap 76 involves the use of navigation function WAYPOINT. These devices are easy to use, the measurement consists in saving the coordinates of the object by holding down the MARK button. The processing of the data starts from copying data from the receiver to the $\mathrm{PC}$, using the appropriate transmission cables and the available software (for example, listed in Table 2).

The selection of underlay content in the QGIS program is possible thanks to the plug "Open Layers Plugin" which allows you to view maps of the Google Maps, Bing, Yahoo and Open Street Map services.

Figure 5 shows a map based on the data obtained using receivers Garmin GPSmap 76 oraz Nautiz x7. The whole elaboration was made in the program QGIS.

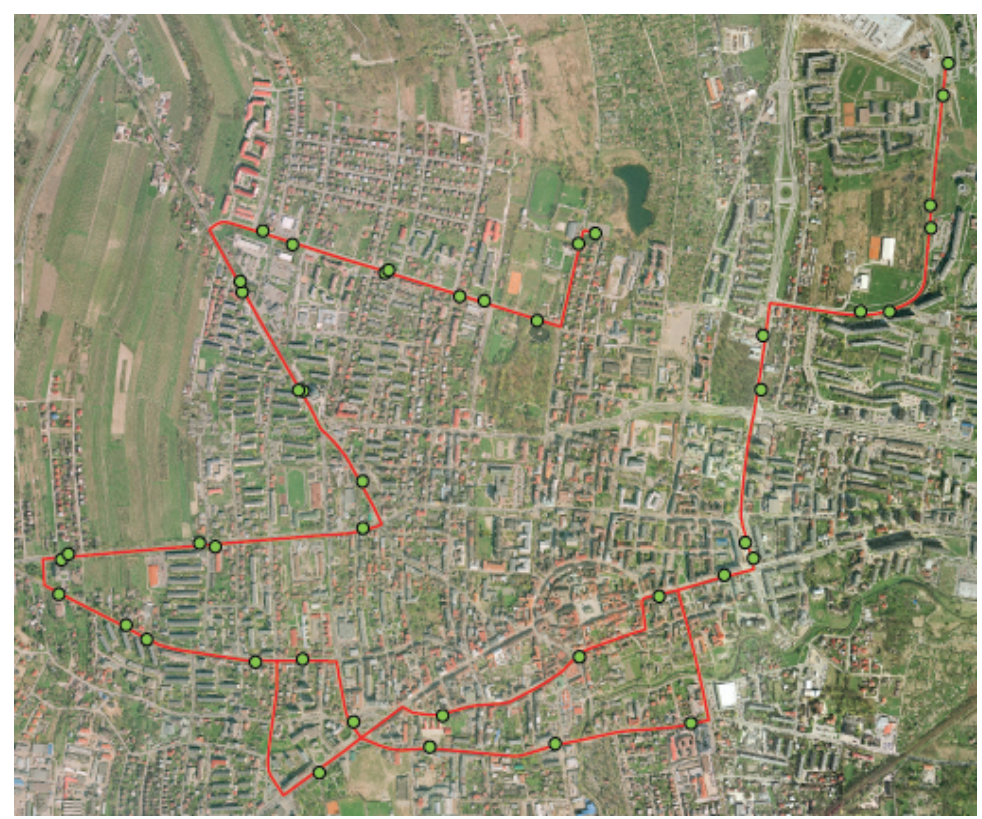

Fig. 5. Map of a public transport bus line in Tarnow on the underlay of Geoportal Source: [1]

In Figures 6 and 7 further examples of preparation of maps using different underlays are shown. Coordinates of the points (monuments of nature in the selected area) were obtained using two receivers Garmin GPSmap 62st and Nautiz x7. The figures show the difference in the acquired coordinates $X, Y$ with using these receivers, which was from $2-5 \mathrm{~m}$. 


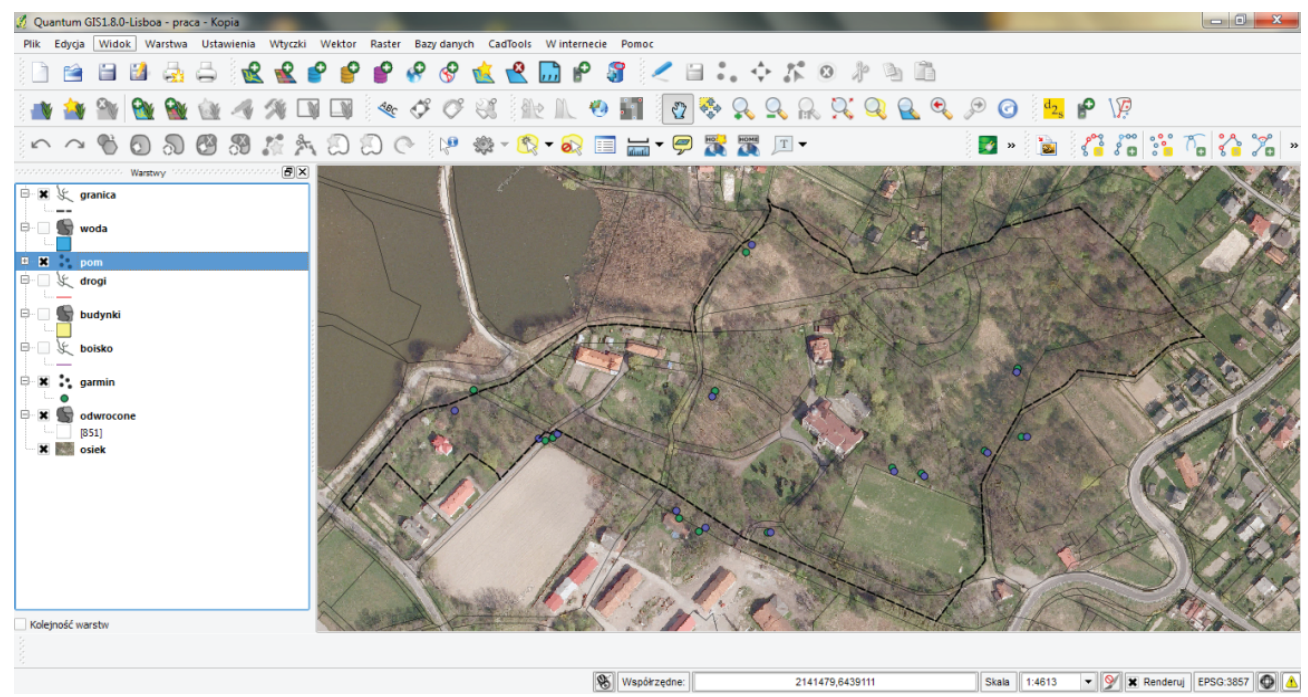

Fig. 6. Example of map with an underlay of Google Hybrid.

Source: [2]

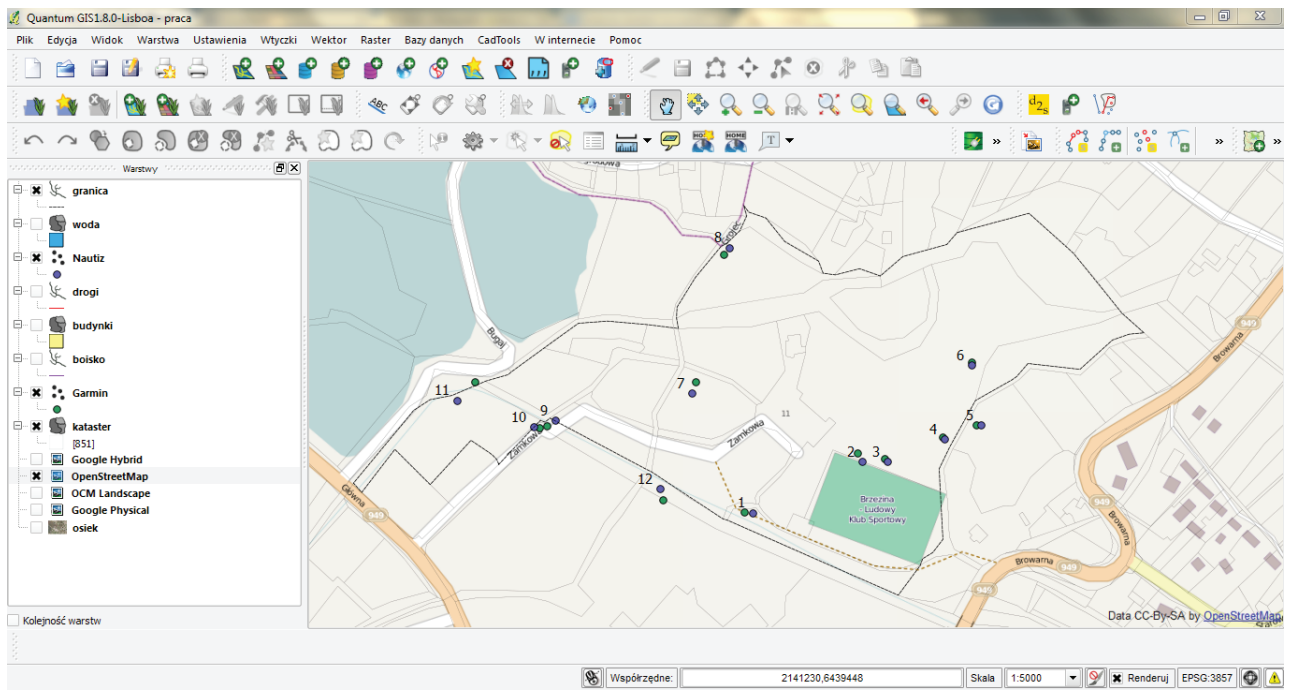

Fig. 7. Map with underlay of Open Street Map

Source: [2]

\section{Conclusions}

Preliminary results of testing three types of hand-held receivers: GPSmap 76, GPSmap 62st and GPS Nautiz X7 considering the possibilities of the use of acquired data to create or update thematic maps, showed a limited degree of their usefulness 
for such purposes. Due to the positioning accuracy of the order of 2-10 m, depending on the type of the receiver (Tab. 2) it seems possible to use them to the least accurate thematic maps created for illustrative or touristic purposes. This conclussion concerns in particular Garmin receivers, which the principal purpose is always navigation. Cartographical studies, developed on the basis of finished and public map underlays using services Open Street Map and Geoportal, shown in Figures 5-7 can be used to identify the approximate location of objects, which were given the nature of the spot on the map (bus stops, monuments of nature, and small architecture objects).

\section{References}

[1] Chmura A.: Ewolucja map tematycznych na przestrzeni wieków. Uniwersytet Rolniczy w Krakowie 2013 [M.Sc. thesis].

[2] Czembor A.: Wykorzystanie GPSmap 76 i GPS Nautiz do prac inwentaryzacyjnych zespotu pałacowo-parkowego w Osieku. Uniwersytet Rolniczy w Krakowie 2013 [M.Sc. thesis].

[3] Kowacka M.: Opracowanie mapy tematycznej z wykorzystaniem GPS do pomiaru elementów małej architektury. Uniwersytet Rolniczy w Krakowie, Kraków [engineering thesis].

[4] Kwinta A., Szeptalin A.: Wykorzystanie ręcznych odbiorników GNSS do pomiarów powierzchni działek rolnych. Infrastruktura i Ekologia Terenów Wiejskich. Polska Akademia Nauk, Oddział w Krakowie, Komisja Technicznej Infrastruktury Wsi PAN, nr 6, 2010, pp. 157-166.

[5] Lamparski J., Świątek K.: GPS w praktyce geodezyjnej. Wydawnictwo Gall, Katowice 2007.

[6] Mika M.: Wykorzystanie ręcznych odbiorników GPS wsystemiejdnolitejpłatności obszarowej dla wyznaczenia pól powierzchni działek. Infrastruktura i Ekologia Terenów Wiejskich. Polska Akademia Nauk, Oddział w Krakowie, Komisja Technicznej Infrastruktury Wsi PAN, nr 3/2011, pp. 53-62.

[7] Medyńska-Gulij B.: Kartografia i geowizualizacja. Wydawnictwo Naukowe PWN, Warszawa 2012.

[8] Siejka M.: Wstepne wyniki eksperymentów z wykorzystaniem systemu EGNOS, wykonanych za pomoca odbiornika Garmin GPSMap 76CSx. Zeszyty Naukowe Akademii Rolniczej nr 431, Geodezja 22, Kraków 2006, pp. 177-184.

[9] Siejka Z.: Analiza aktualnych dokładności i precyzji ręcznego odbiornika GPS z sygnałem EGNOS. Infrastruktura i Ekologia Terenów Wiejskich. Polska Akademia Nauk, Oddział w Krakowie, Komisja Technicznej Infrastruktury Wsi PAN, nr 1/II, 2012, pp. 121-128. 